\title{
EFFECTS OF THE COMBINED ARGINASE AND CANAVANINE TREATMENT ON LEUKEMIC CELLS IN VITRO AND IN VIVO
}

\author{
O. I. VOVK' ${ }^{1}$, O. I. CHEN ${ }^{1,2}$, N. I. IGUMENTSEVA', O. YU. SENCHUK ${ }^{1}$, \\ M. L. BARSKA ${ }^{1}$, N. O. SYBIRNA ${ }^{1,2}$, O. V. STASYK ${ }^{1}$ \\ ${ }^{1}$ Institute of Cell Biology, National Academy of Sciences of Ukraine, Lviv; \\ ${ }^{2}$ Ivan Franko National University of Lviv, Ukraine; \\ e-mail: stasyk@cellbiol.lviv.ua
}

It was previously demonstrated in in vitro experiments that canavanine (Cav), a natural toxic arginine analogue of plant origin, is a promising candidate for augmenting the antineoplastic effects of arginine starvation. We demonstrated herein that recombinant human arginase, an arginine degrading enzyme, abrogated growth and significantly increased Cav cytotoxicity toward cultured L1210 murine leukemic cells. Cav co-treatment further reduced cells viability in a time-dependent manner and significantly promoted apoptosis induction. In the pilot study we also evaluated for the first time the potential toxicity of the combined arginine deprivation and Cav treatment in healthy mice. Administration of Cav alone or in combination with pegylated cobalt-containing human arginase (Co-hARG) did not evoke any apparent toxic effects in these animals, with no significant behavioural and survival changes after several weeks of the treatment. The therapeutic effects of the combination of Co-hARG and Cav were provisionally evaluated on the highly aggressive murine L1210 leukemia, which is semi-sensitive to arginine deprivation as a monotreatment. Combination of two drugs did not result in significant prolongation of the survival of leukemia-bearing mice. Thus, we have shown that the proposed combinational treatment is rather non-toxic for the animals. It has to be further evaluated in animal studies with alternative tumor models and/or drug doses and treatment modalities.

Key words: arginase, canavanine, murine leukemia, animal model.

$\mathrm{P}$ harmacological deprivation of arginine with the recombinant arginine-degrading enzymes, such as arginine deiminase and arginase, is a novel potential approach for cancer treatment currently under clinical trials [1-4]. Arginine-targeted therapies are developing toward combinatorial modalities based on the emerging preclinical data of additive and synergistic drug effects in the treatment of arginine auxotrophic cancers [4-6].

L-Canavanine (Cav), guanidine-containing non-proteinogenic amino acid found in certain leguminous plants [7] is highly toxic for a wide range of organisms including bacteria, fungi, yeasts, algae, plants, insects, and mammals [8]. Due to the remarkable structural similarity of Cav to arginine (Arg), it can effectively compete with Arg for arginyl tRNA synthase and for incorporation into cellular proteins [9]. In addition, Cav, as Arg antimetabolite, is an inhibitor of inducible nitric oxide synthase [10]. L-Canavanine has been reported to possess growth retardation activity toward tumor cells in culture and experimental tumors in vivo [11-13]. Synergistic antitumor effects from a combination of Cav with 5 -fluorouracil or $\gamma$-irradiation have been demonstrated, indicating that Cav may modulate the chemo- or radiosensitivity of tumors [14, 15].

We have recently demonstrated in in vitro experiments that Cav strongly and selectively augments antiproliferative effect of arginine deprivation for various tumor cells but not pseudonormal cells [16]. We also observed that the combined recombinant human arginase (rhARG) and Cav treatment although inhibited proliferation of activated peripheral blood lymphocytes but only slightly promoted apoptosis and did not affect resting cells [17]. In other investigations, we also revealed that rhARG treatment inhibited growth and reduced viability in several acute lymphoblastic leukemia cell lines in vitro and strongly (up to 50 times) decreased $\mathrm{IC}_{50}$ for Cav [18].

From this point of view, it was interesting to evaluate for the first time the feasibility and potential therapeutic effect of the combined arginine dep- 
rivation and Cav treatment. L1210 leukemic cells, which are weakly sensitive to arginine starvation as a monotreatment, were used as an experimental model.

\section{Materials and Methods}

Materials and treatment schedule of animal study. All the manipulations with laboratory animals were carried out according to the European Convention for the Protection of Vertebrate Animals used for Experimental and Other Scientific Purposes (Strasbourg, 1986) and Bioethical expertise of preclinical and other scientific studies conducted on animals (Kyiv, 2006). Adult male C57BL/6 (canavanine cytotoxicity) or DBA/2 (leukemia propagation) mice, aged 8-12 weeks and weighing 19-22 $\mathrm{g}$ at the start of experiment, were maintained on a 12-hour light: dark cycle in temperature controlled room, with access to water and food ad libitum.

In the initial experiments, affinity purified His-tagged secretory recombinant human arginase (rhARG), constructed and purified at the Institute of Cell Biology from yeast Hansenula polymorpha producers [4], was injected at several doses (250$1000 \mathrm{U} /$ mouse) and by different ways of administration (intraperitoneal or intravenous) to verify its effect as an arginine-degrading enzyme. In subsequent experiments pegylated human arginase PEG 5000 Co-hARG, kindly provided by Prof. G. Georgiou (University of Texas, Austin, USA) for our collaborative experimental program with Prof. L. KunzSchughart (OncoRay, TUD, Germany), was used. Further on, we tested for the first time the combined pegylated Co-hARG (6 mg/kg, i.p. once in four days) and Cav (L- canavanine sulfate salt, Sigma-Aldrich, 0.1 or $0.5 \mathrm{~g} / \mathrm{kg}$ i.p. every second day) treatment with regard to possible toxicity, weight changes and survival in healthy animals and L1210 murine leukemia-bearing mice. In the case of experimental leukemia model, drug administration started the next day after i.p. tumor cell inoculation.

Analysis of pharmacokinetics (arginase activity) and pharmacodynamics (arginine concentration) of native rhARG and pegylated Co-hARG in blood plasma of mice was carried out. Blood plasma from tail vein was collected at the indicated time points and arginine level in each sample was determined by high pressure liquid chromatography (HPLC) as described in [19]. We also measured some blood biochemical parameters of Co-ARG and/or Cav treated mice after decapitation. Total protein in blood plas- ma of mice was determined according to Peterson's method [20]. Alanine aminotransferase (ALT) activity, marker of hepatic toxicity, was measured spectrophotometrically by Reitman and Frenkel dinitrophenylhydrazine method at $505 \mathrm{~nm}$ (SIMKO, Lviv, Ukraine) [21]. $\alpha$-amylase, marker of chronic and acute pancreatic toxicity, was assayed by amyloclastic method [22].

Leukemia transplantation and culturing. L1210 murine leukemia in vitro and in vivo sublines were obtained from the tumor strain collection of R. E. Kavetsky Institute of Experimental Pathology, Oncology and Radiobiology, NAS of Ukraine (Kyiv, Ukraine). The tumor was supported by transferring $\sim 0.25 \mathrm{ml}$ of ascitic fluid $\left(2-3 \times 10^{6}\right.$ cells) from donor mouse into the abdominal cavity of recipient mouse. Ascite from the tumor - bearing mice was obtained and transplanted on the $7^{\text {th }}$ day after the inoculation. Tumor growth was controlled by everyday weighting of the mice. The viability and number of cells in the ascitic fluid were checked by cell counting in the hemocytometer in the presence of $0.05 \%$ Trypan blue. The leukemic cell vitality in ascite used for transplantation was not less than $98 \%$.

L1210 in vitro culture subline was cultured in RPMI 1640 medium supplemented with 10\% fetal calf serum (Sigma, USA), $300 \mathrm{mg} / \mathrm{l}$ glutamine and $50 \mu \mathrm{g} / \mathrm{ml}$ gentamycin (Sigma-Aldrich, Germany) in a humidified atmosphere of $5 \% \mathrm{CO}_{2}$ at $37{ }^{\circ} \mathrm{C}$. The cells were subcultivated every 3 days by trypsinization and split in a 1:5 ratio. In experiments, cells were plated in 96-well plates at a density of $3-5 \times 10^{4}$ in RPMI 1640 medium and treated with $2 \mathrm{U} / \mathrm{ml}$ rhARG, Cav (0.1 mM) and/or Cit (0.1 mM) for 24, 48 and $72 \mathrm{~h}$. The dynamics of cell growth were determined in Trypan Blue dye exclusion test (Sigma, USA). The cells were resuspended and aliquots of cells were mixed with the $0.05 \%$ Trypan Blue dye solution and counted on a hemocytometer by means of light microscopy. Concentration- and time-dependent Cav cytotoxicity was measured using the standard MTT assay.

MTT Assay. Cells were grown in 96-well plates with $0,0.01,0.1,1$ and $10 \mathrm{mmol} / \mathrm{l}$ of Cav in either culture complete medium (CM), CM with $2 \mathrm{U} / \mathrm{ml}$ rhARG or/and citrulline $(0.1 \mathrm{mM})$. After different treatments, $20 \mu \mathrm{l}$ of $5 \mathrm{mg} / \mathrm{ml}$ MTT solution (Sigma, USA) was added to each well (0.1 mg/well) and incubated for 5 hrs. The supernatants were aspirated, the purple formazan crystals in each well were dissolved in $200 \mu \mathrm{l}$ of dimethyl sulfoxide and optical 
density at $540 \mathrm{~nm}$ was measured on a Microplate Reader (Biotek, USA). The amount of Cav sufficient to kill $50 \%$ of the cells in a culture was defined as the Cav inhibitory concentration $\left(\mathrm{IC}_{50}\right)$.

Assay of arginase activity. Arginase activity was assayed in $20 \mathrm{mM}$ tris-sulfate buffer, $\mathrm{pH} 9.5$, containing $2 \mathrm{mM} \mathrm{MnCl}_{2}$ and $100 \mathrm{mM}$ arginine in a final volume of $1 \mathrm{ml}$. After the incubation for $30 \mathrm{~min}$ at $37^{\circ} \mathrm{C}$ the reaction was stopped by adding trichloroacetic acid and the resulting urea was assayed by the diacetyl monooxime method spectrophotometrically at $520 \mathrm{~nm}$ [23]. One unit of enzyme activity was defined as the amount of enzyme that releases $1.0 \mu \mathrm{mol}$ of urea for $1 \mathrm{~min}$ under the above conditions.

Western blot analysis [24]. Treated and control cells were washed with ice-cold PBS and lysed in extraction buffer containing $10 \mathrm{mM}$ Tris-HCl (pH 7.5), $150 \mathrm{mM} \mathrm{NaCl}, 1 \%$ NP-40, 5 mM EDTA, $50 \mathrm{mM}$ NaF, $1 \mathrm{mM} \mathrm{Na} \mathrm{VO}_{4}, 5 \mathrm{mM}$ benzamidine, $1 \mathrm{mM}$ PMSF, $2 \mu \mathrm{g} / \mathrm{ml}$ aprotinin, $10 \mu \mathrm{g} / \mathrm{ml}$ leupeptin, $1 \mu \mathrm{g} / \mathrm{ml}$ pepstatin at $4{ }^{\circ} \mathrm{C}$ for $20 \mathrm{~min}$. Cell extracts were obtained after centrifugation at $12000 \mathrm{~g}$ at $4{ }^{\circ} \mathrm{C}$ for $30 \mathrm{~min}$. Equal amounts of total protein were separated on $10 \%$ SDS-PAGE and transferred to PVDF membrane (Millipore Corp., USA). The membranes were blocked in 5\% non-fat dried milk in PBS containing $0.05 \%$ Tween-20 and probed with primary antibodies against argininosuccinate synthetase (ASS, BD Transduction Laboratories), cleaved poly(ADP-ribose) polymerase (cPARP, Cell Signaling Technology) and $\beta$-actin (Sigma-Aldrich) as the loading control. Secondary goat horseradish peroxidase-conjugated anti-mouse antibodies (Millipore Corp.) and an ECL detection system (Millipore Corp.) were used to visualize immunoreactive bands.

Statistical analysis. A group of 6-8 mice was taken in each experiment that was repeated three times. Data are presented as mean \pm SD and the statistical significance of difference was evaluated using MS Excel software for Student's $t$-test $(P<0.05)$.

\section{Results and Discussion}

Arginase and Cav treatment did not produce evident toxic effects in healthy mice. The in vitro and in vivo evaluation of potential medication is a crucial factor in the development of new therapies. Therefore, we first evaluated, whether the combinational arginase and Cav treatment would evoke any toxicity in mice. Recombinant human arginase I (rhARG), expressed by us as a secretory protein in the methylotrophic yeast Hansenula polymorpha and affinity purified [4], was utilized for all in vitro and some in vivo experiments. Analysis of pharmacodynamics (via arginine concentration measured by HPLC) and pharmacokinetics (monitoring arginase activity) in blood plasma of rhARG treated mice demonstrated the low efficacy of this drug in animals due to a short circulation half-life in blood stream. As our preliminary study revealed, the highest injected dose of $500 \mathrm{U}$ of the purified native rhARG reduced circulating free arginine in blood stream only transiently and up to $20 \mu \mathrm{M}$, and concomitantly exhibited fast loss in specific activity (data not shown). The half-life time of the enzyme was estimated to be approximately $3 \mathrm{~h}$.

It was previously reported that replacing the two $\mathrm{Mn}^{2+}$ ions normally present in human arginase I with $\mathrm{Co}^{2+}$ results in an enzyme that displays 10fold higher catalytic efficiency $\left(k_{\text {cat }} / K_{\mathrm{m}}\right)$ for L-Arg hydrolysis and, important for therapeutic applications, significantly increased its serum stability [25]. The authors demonstrated that weekly injection of $8 \mathrm{mg} / \mathrm{kg}$ of Co-hARG induced regression in human hepatocellular (HepG2) and pancreatic (Panc-1) carcinoma tumor xenografts [26].

Therefore, next we utilized in our study the pegylated PEG5K-Co-Arginase (hereinafter CohARG) kindly provided by Prof. L. Kunz-Schughart (OncoRay, TUD Dresden, Germany). Single intraperitoneal (i.p.) injection of Co-hARG (6 mg/kg of body weight) provided complete (at least below the detection level of $0.5 \mu \mathrm{M}$ ) arginine depletion for up to 4 days (Fig. 1, A). It was also observed that plasma Cav level in mice following i.p. single Cav injection at $0.5 \mathrm{~g} / \mathrm{kg}$ dose dropped quickly and was completely exhausted after $3 \mathrm{~h}$ as shown in Fig. 1, B. Because of the small circulation half-life time of Cav in blood stream (within few hours), in the subsequent experiments this drug was administered to animals at the same dose every second day (see below).

There can be several reasons of the observed Cav pharmacodynamics: its urinary excretion by kidneys, cleavage by the administered recombinant arginase or cleavage by host liver arginase [12]. Therefore, we have additionally tested Cav stability in vitro in the presence of Co-hARG. As shown on Fig. $1(C)$, Cav, unlike arginine, when mixed in equimolar concentration and exposed to Co-hARG was not cleaved for at least one hour of the incubation. This data suggests that the two drugs may be 
A

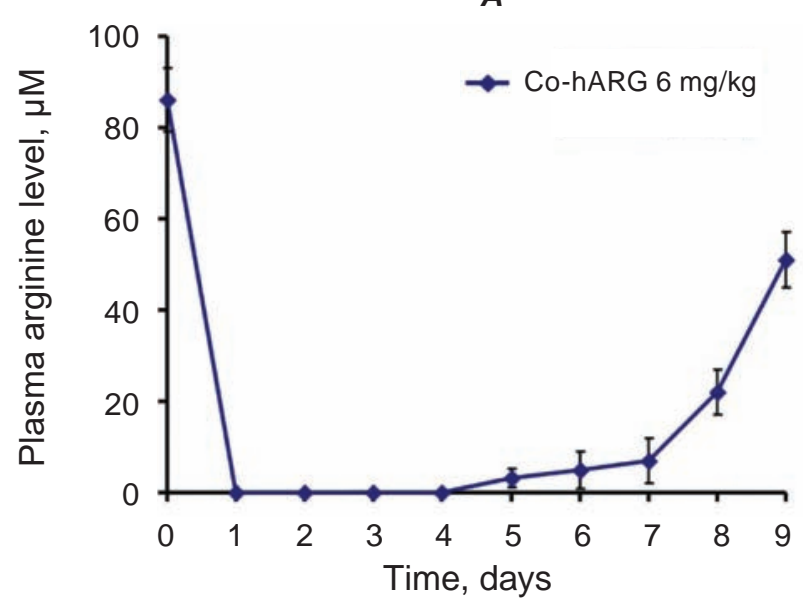

B

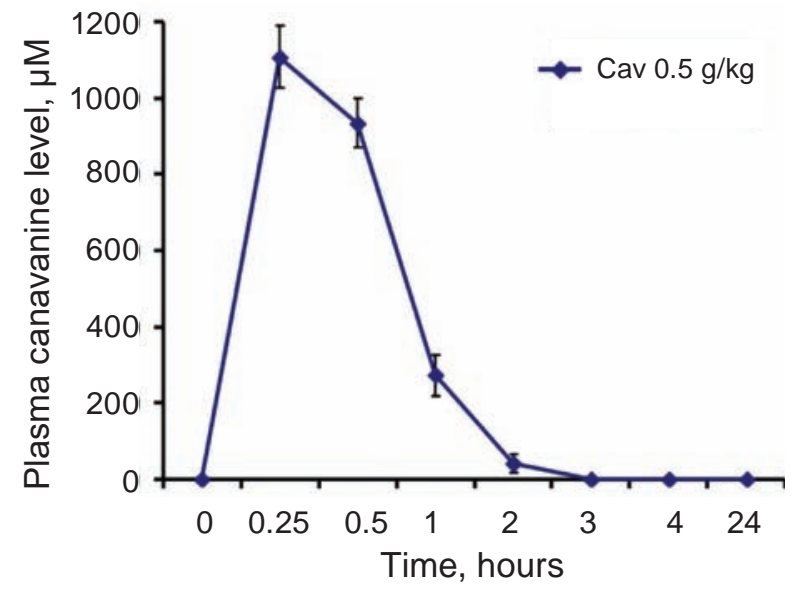

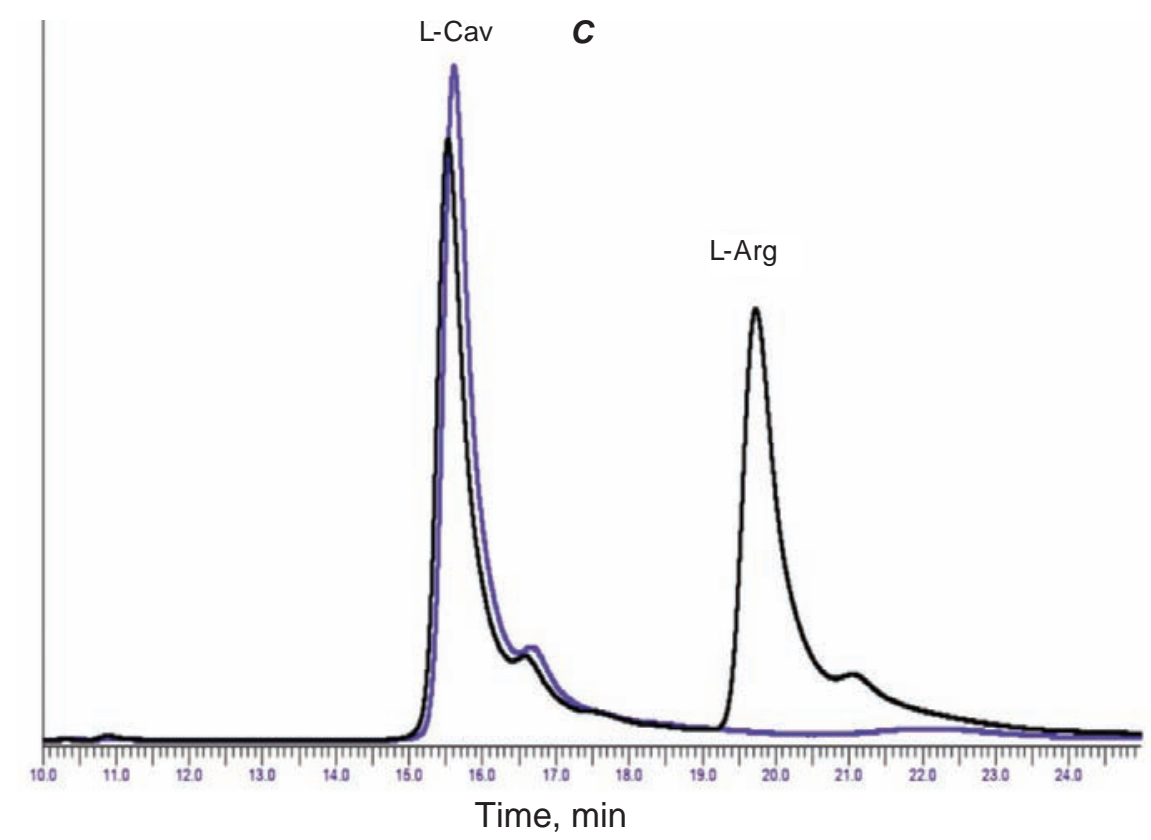

Fig. 1. Pharmacodynamics of pegylated Co-hARG (A) and Cav (B) in blood plasma of mice (measured by HPLC as described in M\&M). C-Overlay chromatograms of mixed $1 \mathrm{mM} \mathrm{L-Arg} \mathrm{and} \mathrm{L-Cav} \mathrm{solution} \mathrm{in} \mathrm{PBS}$ without (Black) or with Co-hARG (2 U/ml, 1 h incubation) (Blue)

compatible as components of the proposed treatment schedule.

Different doses of Cav administered alone (i.p. injection or in drinking water) were tested for toxicity in mice. It was observed that Cav in the range of 0.01 to $1 \mathrm{~g} / \mathrm{kg}$ had no apparent acute animal toxicity (no weight or behavior alterations, data not shown). Next we evaluated the effect of the combined pegylated Co-hARG (6 mg/kg i.p. once in four days) and Cav ( 0.1 or $0.5 \mathrm{~g} / \mathrm{kg}$ i.p. every second day) treatment on healthy mice. It should be stressed that arginine level in the bloodstream of experimental animals was permanently monitored by HPLC. Blood plasma from tail vein was collected at the indicated time points, and arginine content in the samples was found to be either very low (Day 15) or below the level of detection (Table 1).

Administration of both Cav and pegylated CohARG did not produce any apparent toxic effects in these animals (Fig. 2, Table 2), with no significant behavioural or survival changes after two weeks of the treatment.

It should be noted that Co-hARG treated mice were losing their weight in the first few days of experiment which apparently was associated with arginine starvation (see Fig. 2). In the same manner, 
Ta b le 1. Plasma arginine levels $(\mu M)$ in different animal groups during experiment

\begin{tabular}{l|c|c|c|c|c}
\hline \multirow{2}{*}{ Conditions } & \multicolumn{5}{c}{ Experiment duration } \\
\cline { 2 - 6 } & Day 3 & Day 4 & Day 8 & Day 13 & Day 15 \\
\hline Control (untreated mice) & NA & $88 \pm 6$ & $115 \pm 4$ & NA & $106 \pm 6$ \\
Co-hARG 6 mg/kg & NA & ND & ND & NA & $3.3 \pm 1.0$ \\
Co-hARG + Cav 0.5 g/kg & ND & ND & ND & ND & ND \\
Cav 0.1 g/kg & NA & $97 \pm 4$ & NA & $106 \pm 5$ & NA \\
Cav 0.5 g/kg & NA & $85 \pm 7$ & NA & $116 \pm 4$ & NA \\
\hline
\end{tabular}

Note: ND - not detected, NA - not analysed

simultaneous administration of Co-hARG and Cav did not significantly affect the mice body weight (the difference was within less than $10 \%$ at the end of the experiment). It is known from the literature that Cav moves quickly to the liver where hepatic arginase efficiently catalyzes its hydrolysis to urea and canaline and such catabolism coupled with urinary excretion resulted in a rapid drop of blood serum canavanine level before harmful effects were manifested [12]. Since combinational therapy of Co-hARG and Cav has been tested by us in an animal model for the first time, the precise pharmacokinetics of Cav and stoichiometry between hepatic catabolism, hydrolysis in the blood by Co-hARG and tissue consumption requires separate detailed studies.

In order to further evaluate the possible combined effects of Co-hARG and Cav on mice, we also monitored the most commonly used blood biochemical parameters which reflect the function of inter- nal organs of experimental animals. As a marker of inflammation and immune response, we measured total protein concentration in blood plasma of the treated mice. We observed no significant changes in its level in all groups of tested animals (Table 2). The total level of immunoglobulins was unchanged during the treatment (data not shown). Enzyme activity of liver damage marker alanine aminotransferase (ALT) and marker of chronic and acute pancreatic toxicity $\alpha$-amylase also appeared to be within the control range (Table 2).

Simultaneously, we found a marked increase of blood urea level under single Cav treatment or combined with Co-hARG. It is noteworthy that urea level normally found is in a fairly wide range of values (3.2-9.3 $\mathrm{mmol} / \mathrm{l}$ in mice) and its increased level of up to 2 times against the control is not a serious side effect but just an indicator of the metabolic state of organism. Elevated levels of urea in the blood of

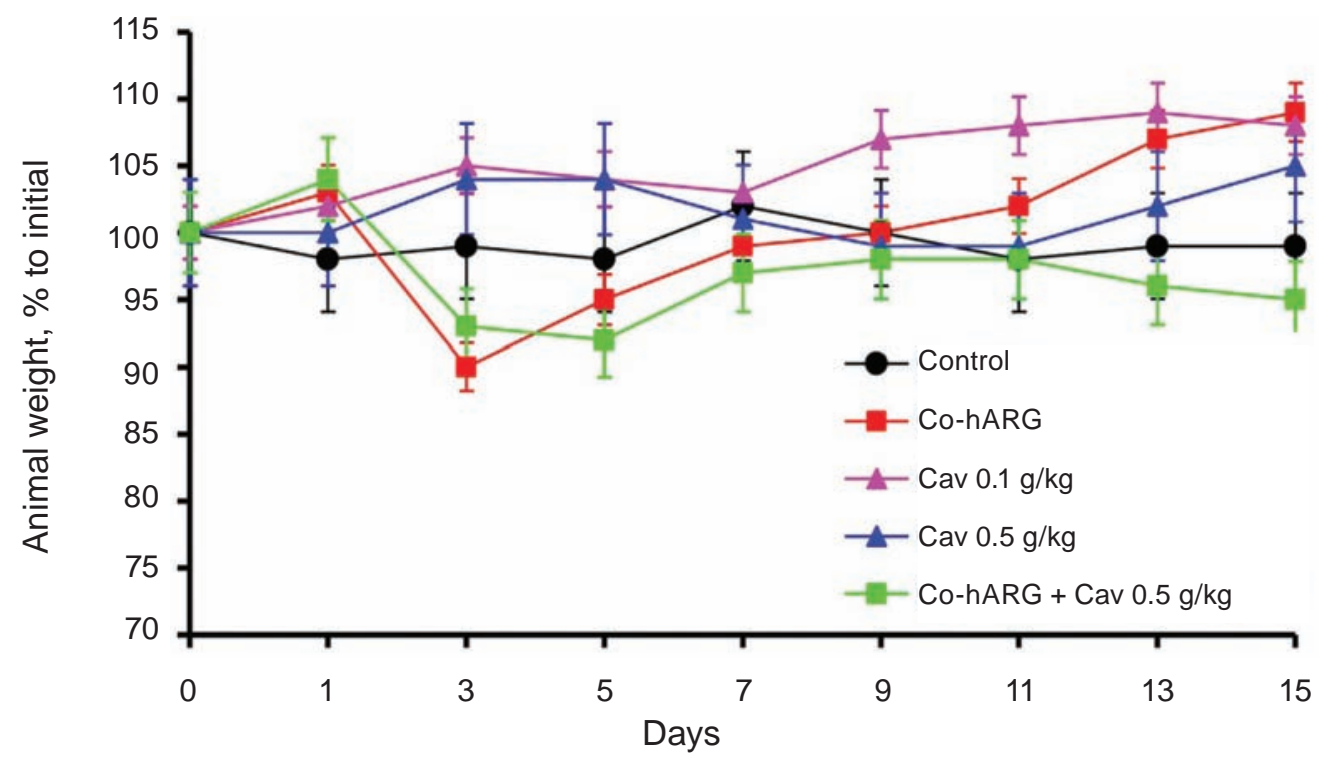

Fig. 2. Effect of the combined Co-hARG and Cav treatment on the weight of healthy mice. Control: mice were i.p. injected daily with $0.15 \mathrm{M} \mathrm{NaCl}$ 
Ta ble 2. Biochemical parameters of blood plasma of Co-hARG and Cav treated mice after 15 days of the treatment

\begin{tabular}{|c|c|c|c|c|c|}
\hline \multirow[b]{2}{*}{ Parameters } & \multicolumn{5}{|c|}{ Conditions } \\
\hline & $\begin{array}{c}\text { Control } \\
\text { (untreated } \\
\text { mice) }\end{array}$ & $\begin{array}{l}\text { Co-hARG, } \\
6 \mathrm{mg} / \mathrm{kg}\end{array}$ & Cav, $0.1 \mathrm{~g} / \mathrm{kg}$ & Cav, $0.5 \mathrm{~g} / \mathrm{kg}$ & $\begin{array}{c}\text { Co-hARG } \\
(6 \mathrm{mg} / \mathrm{kg})+ \\
\text { Cav }(0.5 \mathrm{~g} / \mathrm{kg})\end{array}$ \\
\hline Total protein (g/l) & $75 \pm 8$ & $65 \pm 12$ & $77 \pm 9$ & $79 \pm 6$ & $78 \pm 8$ \\
\hline $\begin{array}{l}\text { Alanine amino- } \\
\text { transferase (ALT, U/l) }\end{array}$ & $48 \pm 6$ & $33 \pm 9$ & $50 \pm 7$ & $54.7 \pm 6.0$ & $39.6 \pm 8.0$ \\
\hline$\alpha$-amylase $(\mathrm{g} \cdot \mathrm{h} / \mathrm{l})$ & $20 \pm 7$ & $25 \pm 8$ & $29 \pm 6$ & $25.5 \pm 7.0$ & $25 \pm 8$ \\
\hline Urea (mmol/l) & $5.1 \pm 3.0$ & $8.0 \pm 5.0^{*}$ & $8.6 \pm 6.0^{*}$ & $8.2 \pm 7.0 *$ & $9.6 \pm 5.0^{*}$ \\
\hline $\begin{array}{l}\text { Liver weight (\% of } \\
\text { animal weight) }\end{array}$ & $6.8 \pm 0.8$ & $7.7 \pm 1.3^{*}$ & $8.0 \pm 1.3^{*}$ & $9.0 \pm 1.4^{*}$ & $8.0 \pm 1.2^{*}$ \\
\hline
\end{tabular}

Note: * difference in comparison with the control group is significant, $P<0.05$

mice under the Co-hARG treatment very probably may be caused by Co-hARG-mediated enzymatic degradation of plasma arginine to urea and ornithine. Also activation of the total protein breakdown in the whole body under arginine starvation can increase the release of ammonia which is eventually converted to relatively non-toxic urea for excretion [3]. The reason for the observed increase in blood urea in the case of Cav administration may be due to the activation of the Cav hydrolysis to urea by hepatic arginase. Nevertheless, the urea level was not proportional to the applied Cav dose as it should be in that case. At the same time, Co-hARG and Cav co-treatment evoked the apparent cumulative but not additive effect on the increase in serum urea level (Table 2).

We hypothesize that the simultaneous limited increase in the liver weight can be linked to metabolic adaptation of this organ to hepatocellular hypertrophy [27], which is due to the increased demand for hepatic arginase to split Cav. However, these changes under Cav single treatment and under the combined action of Co-hARG plus Cav can be considered as an adaptive and a non-adverse reaction whereas total protein concentration and ALT activity in plasma remained unchanged. Insignificant increase of amylase activity may be due to nephron tension concerning excretion the increased amount of urea in urine. Taking into account all the abovementioned, we can conclude that administration of Cav alone or in combination with Co-hARG did not cause any apparent acute toxic effects in healthy animals, with no significant behavioural or survival changes. It should be emphasized that the chosen doses of Cav (based on very limited literature data and extrapolation of our previous studies in vitro) is rather high and will probably not be used for the therapy. However, these data can be useful as a starting point for developing the novel drug regimens in combinational therapy.

The effect of combined rhARG and Cav treatment on murine L1210 leukemic cells in vitro. As an easy to handle experimental model to study the effects of rhARG and Cav therapy L1210 murine leukemic cells were chosen. First of all, we examined cytotoxic effect of Cav (the concentration that causes death of $50 \%$ of cells, $\mathrm{IC}_{50}$ ) toward L1210 murine leukemic cells upon different culture conditions. For this purpose, tested cells were treated with several increasing concentrations of Cav (0.01, 0.1, 1 and $10 \mathrm{mmol} / \mathrm{l}$ ) in complete medium (CM) alone or in combination with purified rhARG in concentration of $2 \mathrm{U} / \mathrm{ml}$ or/and citrulline $(0.1 \mathrm{mM})$. Using MTT test it was found that Cav cytotoxicity significantly increased in a time-dependent manner under the conditions of Arg starvation. The appropriate Cav $\mathrm{IC}_{50}$ values are provided in Table 3 . In the medium with rhARG, Cav-mediated cytotoxic concentration at 48 or $78 \mathrm{~h}$ of the treatment was approximately one order of magnitude lower relative to $\mathrm{IC}_{50}$ value in control complete medium. Prosurvival effect of $0.1 \mathrm{mM}$ citrulline as arginine precursor on $\mathrm{Cav} \mathrm{IC}_{50}$ was observed only transiently on the first day of incubation.

Next, to evaluate leukemic cell responsiveness to combined rhARG and Cav treatment, the survival rate of cultured L1210 cells was analyzed under the conditions of arginine deprivation (complete medium with the addition of recombinant hu- 
Ta b le 3. The $I_{50}$ value of Cav toward L1210 cells

\begin{tabular}{l|c|c|c}
\hline \multicolumn{1}{c|}{ Cav IC $_{50}, \mathrm{mM}$} & $24 \mathrm{~h}$ & $48 \mathrm{~h}$ & $72 \mathrm{~h}$ \\
\hline Complete medium (CM) & $9.5 \pm 0.3$ & $4.5 \pm 0.3$ & $3.60 \pm 0.15$ \\
$\mathrm{CM}+$ rhARG (2 U/ml) & $6.4 \pm 0.5^{*}$ & $0.6 \pm 0.1^{*}$ & $0.20 \pm 0.05^{*}$ \\
$\mathrm{CM}+$ rhARG + Cit 0.1 mM & $0.80 \pm 0.15^{*}$ & $0.50 \pm 0.08^{*}$ & $0.23 \pm 0.06^{*}$ \\
\hline
\end{tabular}

Note: * difference in comparison with the control (complete medium) to the appropriate hour is significant, $P<0.05$

man arginase rhARG in concentration of $2 \mathrm{U} / \mathrm{ml}$ ) and under the combined starvation for arginine with Cav (rhARG + Cav $0.1 \mathrm{mmol} / \mathrm{l}$ ) and/or citrulline (Cit $0.1 \mathrm{mmol} / \mathrm{l}$ ) (Fig. 3, A). For this purpose, cells were incubated in cell culture medium supplemented with appropriate compounds and a number of viable cells was counted by the trypan blue dye exclusion assay.

We observed that the presence of Cav in complete medium leads to a slight decrease in the number of viable cells starting only after $72 \mathrm{~h}$. As was established before, this weak effect is due to competition of Cav with Arg in several metabolic reactions [28]. It should be noted that rhARG, namely arginine starvation, abrogated growth of L1210 cells and the addition of Cav further reduced cells viability (Fig. 3, A). However, arginine precursor citrulline significantly but not completely counteracted the inhibitory effect of rhARG alone or combined with Cav in L1210 cells due to their apparent positive status for argininosuccinate synthetase (ASS), a rate-
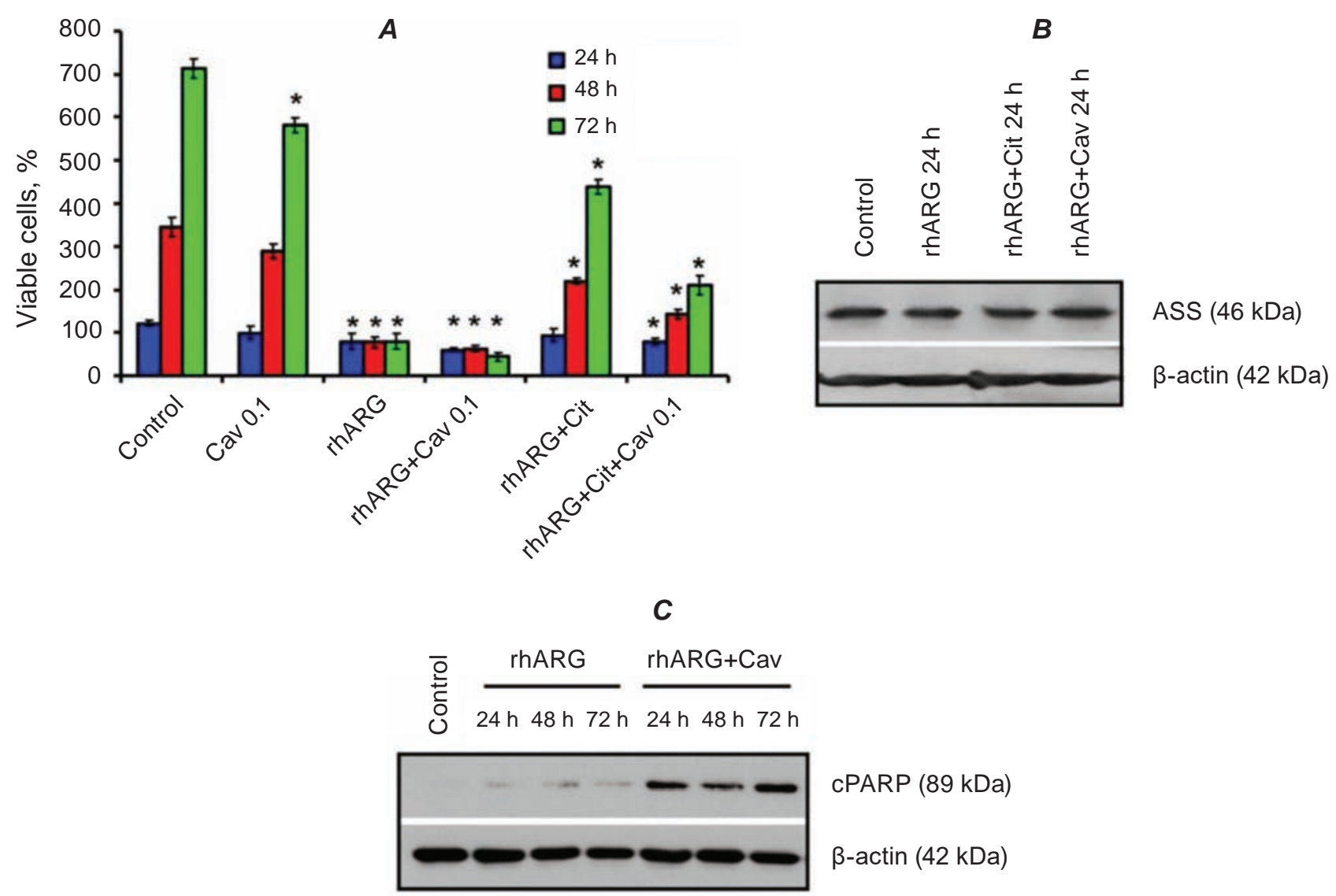

Fig. 3. Viability of cultured L1210 murine leukemia cells under rhARG (2 U/ml) and Cav (0.1 mM) or citrulline (Cit, $0.1 \mathrm{mM}$ ) treatment (A) and Western blot analysis of argininosuccinate synthetase (ASS, B) and cleaved poly(ADP-ribose) polymerase (cPARP, C) level. * Difference in comparison with the control to the appropriate hour is significant, $P<0.05$ 
limiting enzyme of citrulline to arginine conversion in urea cycle (Fig. 3, B).

We also examined whether a combined rhARG and Cav induces apoptosis in L1210 cells that may be concomitant to the observed decrease in their viability (see Fig. 3, A). Indeed, we detected that the expression of the cleaved form of PARP protein (as an apoptotic marker) in L1210 cells significantly increased only after combined rhARG and Cav treatment (see Fig. 3, C). However, rhARG alone only slightly promoted apoptosis induction.

Overall, our data indicate that although viability of L1210 leukemic cells is negatively affected by Cav under Arg restriction, their sensitivity to this compound, as well as to arginine deprivation as a monotreatment is lower relative to other tested malignant cells of leukemic origin and those of solid tumors $[16,18]$.

Evaluation of the effect of combined arginine deprivation and canavanine treatment in animal model of leukemia. A highly aggressive L1210 murine leukemia, shown to be, however, semi-sensitive to arginine deprivation in vitro, was used as a primary screening animal model for preliminary evaluation of the combinational treatment of Co-hARG and Cav. The data on everyday weight dynamics of the treated animals presented in Fig. $4(A)$ demonstrates a tendency toward retardation in the tumor develop-
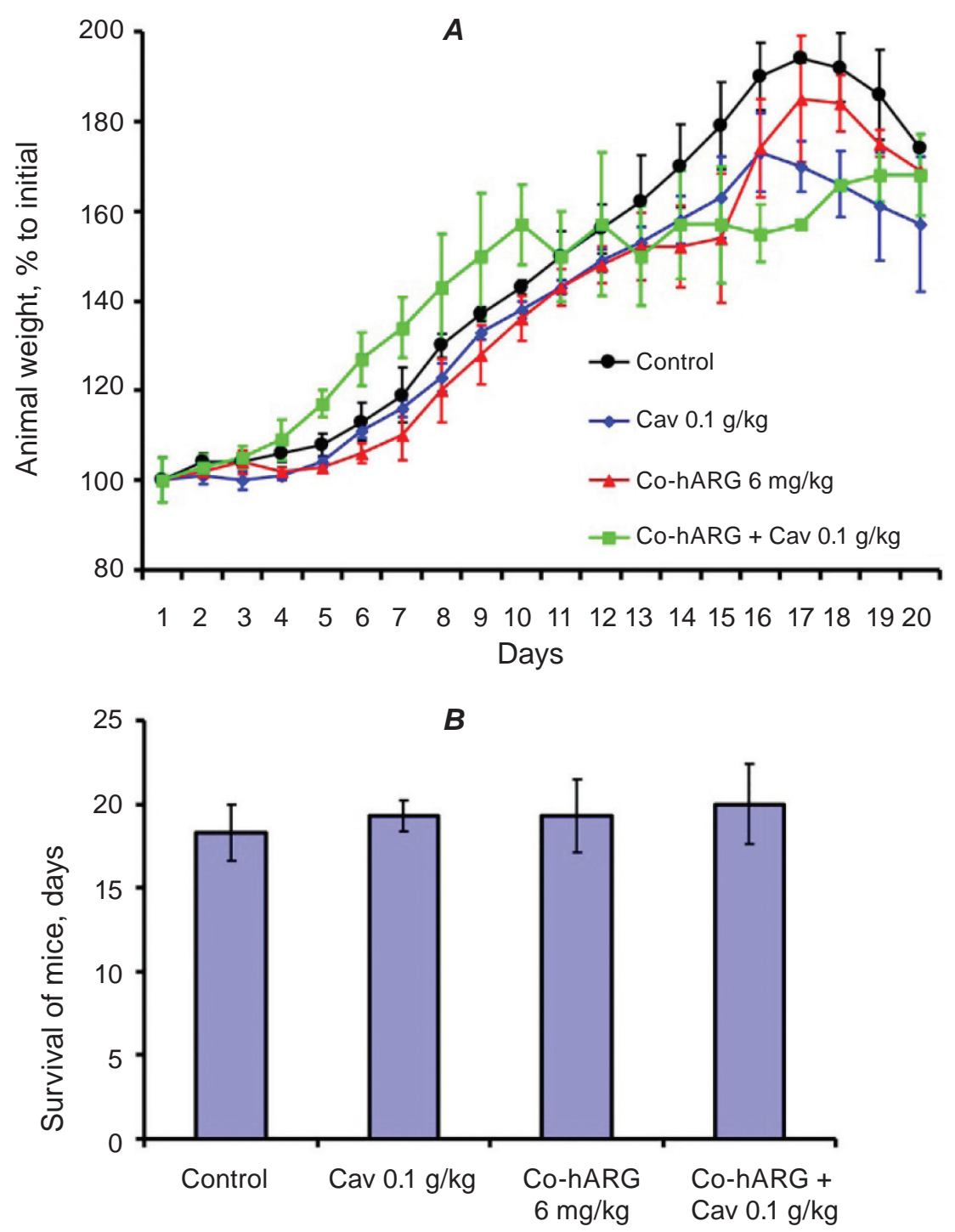

Fig. 4. Effect of i.p. administration of Co-hARG and canavanine on weight changes (A) and survival (B) of L1210-bearing DBA/2 mice (2 mln L1210 cells/mouse). *Control - untreated tumor-bearing mice 
ment as compared to control in the case of the Cav introduction alone and together with Co-hARG. This tendency did not result in significant increase of experimental animals' lifespan under administration of arginase and Cav (Fig. 4, B).

In summary, based on the analysis of commonly used physiological and biochemical parameters of the experimental animals, we can conclude that the proposed combinational treatment with recombinant pegylated Co-hARG and Cav proved to be rather non-toxic for the healthy mice. Although the combined rhARG and Cav treatment of L1210 murine leukemic cells indicated the strong negative impact of Cav on cell viability under arginine restriction in vitro, the chosen combination of these two drugs in vivo did not result in significant prolongation of the survival of L1210 leukemia-bearing mice. This data can be a useful starting point for further development of the novel drug regimens. Also, the effect of this combinational therapy has to be further evaluated in animals with alternative tumor models, in particular on those with ASS-negative status.

\section{Acknowledgements}

The authors are grateful to Prof. DrSc M. Lootsik (Institute of Cell Biology, Lviv, Ukraine) for the invaluable help with some of the experiments described in this study.

\section{КОМБІНАЦЙНИЙ ВПЛИВ АРГІНАЗИ I КАНАВАНІНУ НА ЛЕЙКОЗНІ КЛІТИНИ IN VITRO TA IN VIVO}

\author{
О. I. Вовк ${ }^{1}$, О. I. Чень ${ }^{1,2}$, Н. I. Ігуменцева ${ }^{1}$, \\ О. Ю. Сенчук', М. Л. Барська ${ }^{1}$, \\ H. О. Сибірна ${ }^{1,2}$, О. В. Стасик ${ }^{1}$
}

${ }^{1}$ Інститут біології клітини НАН України, Львів;

${ }^{2}$ Львівський національний університет імені Івана Франка, Україна; e-mail: stasyk@cellbiol.lviv.ua

Як було показано раніше в експериментах in vitro, канаванін (Cav), природний токсичний аналог аргініну рослинного походження, є перспективним кандидатом для посилення протипухлинного впливу голодування за аргініном. $\mathrm{У}$ цій роботі ми показали, що рекомбінантна аргіназа людини як ензим деградації аргініну припиняла ріст i значно підвищувала цитотоксичність Cav по відношенню до культивованих L1210 мишачих лейкозних клітин. Cav за умов голодування за аргініном додатково зни- жував життєздатність клітин залежно від часу інкубації й істотно сприяв індукції апоптозу. У цьому пілотному дослідженні ми також вперше оцінили потенційну токсичність комбінаційного застосування дефіциту аргініну i Cav на здорових мишах. Введення лише Cav або Cav у комбінації 3 пегільованою кобальтвмісною аргіназою людини (Co-hARG) не спричинювало очевидних токсичних ефектів та істотних змін у поведінці і виживанні тварин після кількох тижнів експерименту. Терапевтичні впливи комбінації Co-hARG i Cav були попередньо досліджені на високоагресивній формі мишачого лейкозу L1210, яка є слабочутливою до голодування за аргініном за монотерапії. Комбінація цих двох препаратів не призвела до значної пролонгації виживання мишей-носіїв пухлин. Таким чином, ми показали, що запропонована комбінаційна терапія загалом є нетоксичною для експериментальних тварин. Вона буде в подальшому досліджуватися в експериментах на тваринах 3 альтернативними моделями пухлин та/або різними дозами лікарських засобів і методами лікування.

К л юч о в і с лов а: аргіназа, канаванін, мишачий лейкоз, експериментальні тварини.

\section{КОМБИНИРОВАННОЕ ВЛИЯНИЕ АРГИНАЗЫ И КАНАВАНИНА НА ЛЕЙКОЗНЫЕ КЛЕТКИ IN VITRO И IN VIVO}

\author{
Е. И. Вовк ${ }^{1}$ О. И. Чень ${ }^{1,2}$, Н. И. Игуменцева ${ }^{1}$, \\ А. Ю. Сенчук', М. Л. Барская ${ }^{1}$, \\ Н. А. Сибирная ${ }^{1,2}$, О. В. Стасык ${ }^{1}$
}

${ }^{1}$ Институт биологии клетки НАН Украины, Львов;

${ }^{2}$ Львовский национальный университет имени Ивана Франко, Украина; e-mail: stasyk@cellbiol.lviv.ua

Как было показано ранее в экспериментах in vitro, канаванин (Cav), природный токсический аналог аргинина растительного происхождения, является перспективным кандидатом для усиления противоопухолевого воздействия голодания по аргинину. В данной работе мы показали, что рекомбинантная аргиназа человека, как аргининдеградирующий энзим, прекращала рост и значительно повышала цитотоксичность Cav по отношению к культивированным L1210 мышиным лейкозным клеткам. Cav в условиях 
голодания по аргинину дополнительно снижал жизнеспособность клеток в зависимости от времени инкубации и существенно способствовал индукции апоптоза. В этом пилотном исследовании мы также впервые оценили потенциальную токсичность комбинированного применения дефицита аргинина и Cav у здоровых мышей. Введение одного лишь Cav или Cav в комбинации с пегилированной кобальтсодержащей аргиназой человека (Co-hARG) не вызывало каких-либо явных токсических эффектов и существенных изменений в поведении и выживании у этих животных после нескольких недель эксперимента. Терапевтические эффекты комбинации СоhARG и Cav были предварительно исследованы на высокоагрессивной форме мышиного лейкоза L1210, которая является слабочувствительной к голоданию по аргинину при монотерапии. Комбинация этих двух препаратов не привела к значительной пролонгации выживания мышей-опухоленосителей. Таким образом, мы показали, что предложенная комбинированная терапия в целом является нетоксичной для экспериментальных животных. Она будет в дальнейшем исследоваться в экспериментах на животных с альтернативными моделями опухолей и/или разными дозами лекарственных средств и методами лечения.

К л ю ч е в ы е с л о в а: аргиназа, канаванин, мышиный лейкоз, экспериментальные животные.

\section{References}

1. Ott PA, Carvajal RD, Pandit-Taskar N, Jungbluth AA, Hoffman EW, Wu BW, Bomalaski JS, Venhaus R, Pan L, Old LJ, Pavlick AC, Wolchok JD. Phase I/II study of pegylated arginine deiminase (ADI-PEG 20) in patients with advanced melanoma. Invest New Drugs. 2013; 31(2): 425-434.

2. Yau T, Cheng PN, Chan P, Chen L, Yuen J, Pang R, Fan ST, Wheatley DN, Poon RT. Preliminary efficacy, safety, pharmacokinetics, pharmacodynamics and quality of life study of pegylated recombinant human arginase 1 in patients with advanced hepatocellular carcinoma. Invest New Drugs. 2015; 33(2): 496504.

3. Qiu F, Huang J, Sui M. Targeting arginine metabolism pathway to treat arginine-dependent cancers. Cancer Lett. 2015; 364(1): 1-7.
4. Stasyk OV, Boretsky YR, Gonchar MV, Sibirny AA. Recombinant arginine-degrading enzymes in metabolic anticancer therapy and bioanalytics. Cell Biol Int. 2015; 39(3): 246-252.

5. Phillips MM, Sheaff MT, Szlosarek PW. Targeting arginine-dependent cancers with arginine-degrading enzymes: opportunities and challenges. Cancer Res Treat. 2013; 45(4): 251262.

6. Feun LG, Kuo MT, Savaraj N. Arginine deprivation in cancer therapy. Curr Opin Clin Nutr Metab Care. 2015; 18(1): 78-82.

7. Rosenthal GA. Plant nonprotein amino and imino acids: biological, biochemical, and toxicological properties, Academic Press, New York NY, 1982; 95.

8. Blind PJ, Waldenström A, Berggren D, Ronquist G. Antitumour effect of L-2,4 diaminobutyric acid on a hepatoma cell line. Anticancer Res. 2000; 20(6B): 4275-4278.

9. Rosenthal GA, In: Singh BK, Flores HE, Shannon JC. (eds) Biosynthesis and molecular regulation of aminoacids in plants, American society of plant physiologists, Rockville, MD, 1992; 249.

10. Umans JG, Samsel RW. L-canavanine selectively augments contraction in aortas from endotoxemic rats. Eur J Pharmacol. 1992; 210(3): 343-346.

11. Green MH, Brooks TL, Mendelsohn J, Howell SB. Antitumor activity of L-canavanine against L1210 murine leukemia. Cancer Res. 1980; 40(3): 535-537.

12. Thomas DA, Rosenthal GA, Gold DV, Dickey K. Growth inhibition of a rat colon tumor by L-canavanine. Cancer Res. 1986; 46(6): 28982903.

13. Swaffar DS, Ang CY, Desai PB, Rosenthal GA. Inhibition of the growth of human pancreatic cancer cells by the arginine antimetabolite L-canavanine. Cancer Res. 1994; 54(23): 6045 6048.

14. Green MH, Ward JF. Enhancement of human tumor cell killing by L-canavanine in combination with gamma-radiation. Cancer Res. 1983; 43(9): 4180-4182.

15. Swaffar DS, Ang CY. Growth inhibitory effect of L-canavanine against MIA PaCa-2 pancreatic cancer cells is not due to conversion to its toxic metabolite canaline. Anticancer Drugs. 1999; 10(1): 113-118. 
16. Vynnytska BO, Mayevska OM, Kurlishchuk YV, Bobak YP, Stasyk OV. Canavanine augments proapoptotic effects of arginine deprivation in cultured human cancer cells. Anticancer Drugs. $2011 \mathrm{Feb}$;22(2):148-57.

17. Chen O, Kavalets B, Barska M, Lyniv L, Vovk O, Sybirna N, Stasyk O. Effect of combinational arginase and canavanine treatment on normal human peripheral blood lymphocytes in vitro. Curr Issues Pharm Med Sci. 2013; 26(4): 385389.

18. Chen O, Kavaletz B, Lyniv L, Barska M, Vovk O, Sybirna N, Stasyk O. Effect of combinational arginine deprivation-based enzymotherapy (CADE) with canavanine on viability of human leukemic cells in vitro/ International symposium on Cell Biology jointly with $3^{\text {rd }}$ Ukrainian Congresss for Cell Biology. Yalta, Ukraine, 2012. P. 99.

19. Chen O, Barska M, Sybirna N, Stasyk O. Development and evaluation of HPLC method for arginine assay in biological samples. Visnyk Lviv Univ. Series Biology. 2012; 60: 73-82.

20. Peterson GL. A simplification of the protein assay method of Lowry et al. which is more generally applicable. Anal Biochem. 1977; 83(2): 346-356.

21. Menshikova VV. Laboratory methods of investigation in the clinic. M.: Medicina, 1987. 190 p. (in Russian).

22. Caraway WT. A stable starch substrate for the determination of amylase in serum and other body fluids. Am J Clin Pathol. 1959; 32(1): 97-99.
23. Marsh WH, Fingerhut B, Miller H. Automated and manual direct methods for the determination of blood urea. Clin Chem. 1965; 11: 624-627.

24. Towbin H, Staehelin T, Gordon J. Electrophoretic transfer of proteins from polyacrylamide gels to nitrocellulose sheets: procedure and some applications. Biotechnology. 1992; 24: 145-149.

25. Stone EM, Glazer ES, Chantranupong L, Cherukuri P, Breece RM, Tierney DL, Curley SA, Iverson BL, Georgiou G. Replacing $\mathrm{Mn}(2+)$ with $\mathrm{Co}(2+)$ in human arginase $\mathrm{i}$ enhances cytotoxicity toward l-arginine auxotrophic cancer cell lines. ACS Chem Biol. 2010; 5(3): 333-342.

26. Glazer ES, Stone EM, Zhu C, Massey KL, Hamir AN, Curley SA. Bioengineered human arginase I with enhanced activity and stability controls hepatocellular and pancreatic carcinoma xenografts. Transl Oncol. 2011; 4(3): 138-146.

27. Hall AP, Elcombe CR, Foster JR, Harada T, Kaufmann W, Knippel A, Küttler K, Malarkey DE, Maronpot RR, Nishikawa A, Nolte T, Schulte A, Strauss V, York MJ. Liver hypertrophy: a review of adaptive (adverse and non-adverse) changes-conclusions from the $3^{\text {rd }}$ International ESTP Expert Workshop. Toxicol Pathol. 2012; 40(7): 971-994.

28. Bence AK, Crooks PA. The mechanism of L-canavanine cytotoxicity: arginyl tRNA synthetase as a novel target for anticancer drug discovery. J Enzyme Inhib Med Chem. 2003; 18(5): 383-394. 